Prepared in cooperation with the Louisiana Department of Transportation and Development

\title{
Water Resources of St. James Parish, Louisiana
}

\section{Introduction}

Information concerning the availability, use, and quality of water in St. James Parish, Louisiana (fig. 1), is critical for proper water-supply management. The purpose of this fact sheet is to present information that can be used by water managers, parish residents, and others for stewardship of this vital resource. Information on the availability, past and current use, use trends, and water quality from groundwater and surface-water sources in the parish is presented. Previously published reports (see References Cited section) and data stored in the U.S. Geological Survey's National Water Information System (http://waterdata. usgs.gov/nwis) are the primary sources of the information presented here.

In 2010, about 192 million gallons per day (Mgal/d) of water were withdrawn in St. James Parish, Louisiana, including about $190 \mathrm{Mgal} / \mathrm{d}$ from surface-water sources and $2.85 \mathrm{Mgal} / \mathrm{d}$ from groundwater sources ${ }^{1}$ (table 1). Withdrawals for industrial use accounted for 92 percent of the total water withdrawn (table 2). Other categories of use included public supply, rural domestic, livestock, general irrigation, and aquaculture. Withdrawals for industrial use from surface-water sources have been the dominant component of total water withdrawals since 1970 (U.S. Geological Survey, 2014b). Water-use data collected at 5-year intervals from 1960 to 2010 indicated that withdrawals peaked in 1980 (fig. 2).

\footnotetext{
${ }^{1}$ Water-withdrawal data are based on estimated or reported site-specific data and aggregated data, which are distributed to sources. For a full description of water-use estimate methodology, see "Data Collection" in Sargent (2011). Tabulation of numbers across text and tables may result in different totals because of rounding; nonrounded numbers are used for calculation of totals.
}

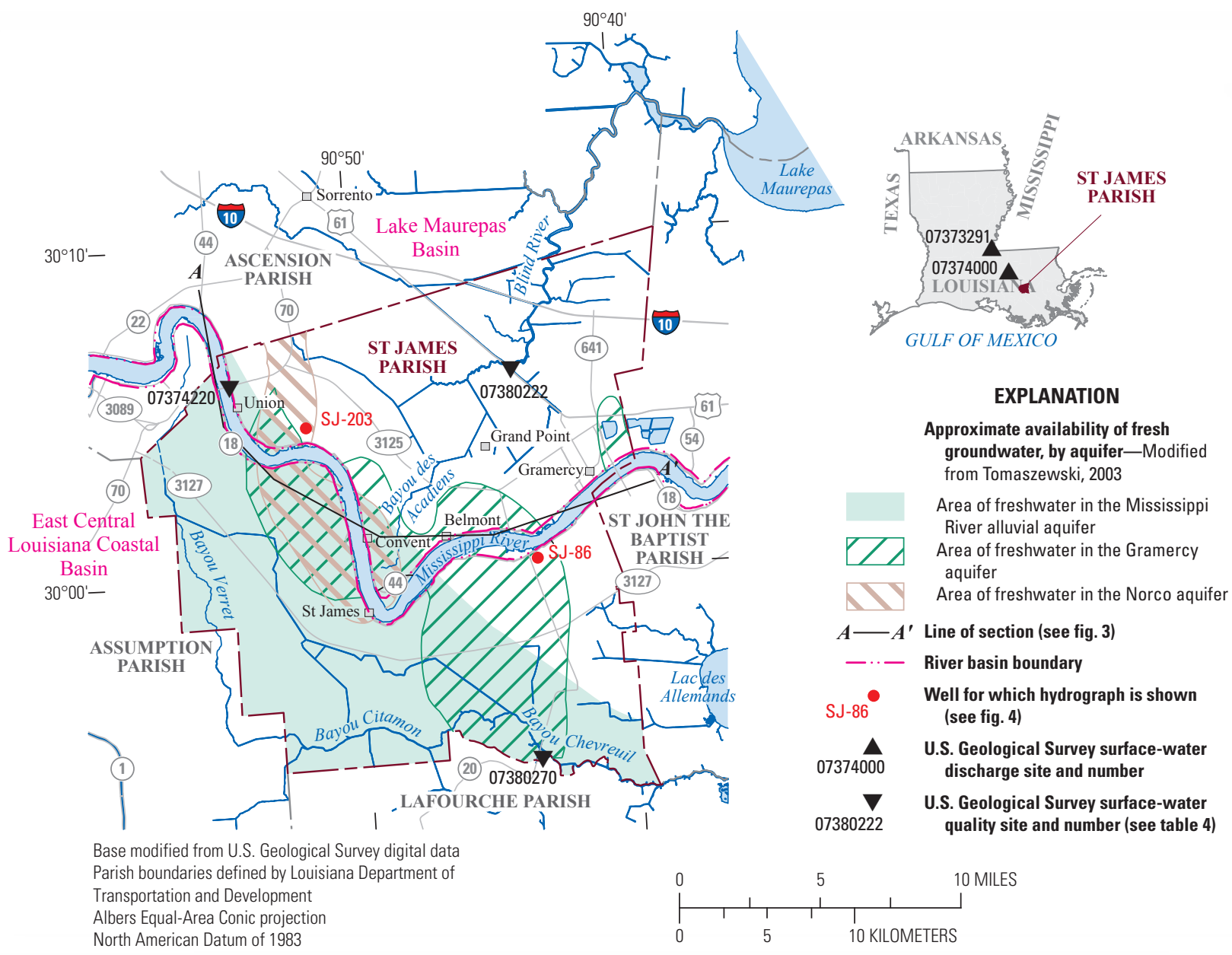

Figure 1. Location of study area, St. James Parish, Louisiana. 
Table 1. Water withdrawals, in million gallons per day, by source in St. James Parish, Louisiana, 2010 (Sargent, 2011; B.P. Sargent, unpub. data, 2011).

$[<$, less than $]$

\begin{tabular}{lcr}
\hline \multicolumn{1}{c}{ Aquifer or surface-water body } & Groundwater & $\begin{array}{c}\text { Surface } \\
\text { water }\end{array}$ \\
\hline Mississippi River alluvial aquifer & 0.01 & \\
Gramercy aquifer & 2.84 & \\
Norco aquifer & $<0.01$ & \\
Mississippi River & & 177.65 \\
Miscellaneous streams & & 11.88 \\
Total & $\mathbf{2 . 8 5}$ & $\mathbf{1 8 9 . 5 3}$ \\
\hline
\end{tabular}

Table 2. Water withdrawals, in million gallons per day, by use category in St. James Parish, Louisiana, 2010 (modified from Sargent, 2011).

$[<$, less than $]$

\begin{tabular}{lccr}
\hline \multicolumn{1}{c}{ Use category } & Groundwater & Surface water & \multicolumn{1}{c}{ Total } \\
\hline Public supply & 0.00 & 3.12 & 3.12 \\
Industrial & 2.83 & 174.52 & 177.36 \\
Rural domestic & 0.01 & 0.00 & 0.01 \\
Livestock & $<0.01$ & 0.00 & 0.00 \\
General irrigation & 0.00 & 0.06 & 0.06 \\
Aquaculture & 0.00 & 11.82 & 11.82 \\
\cline { 2 - 4 } Total & $\mathbf{2 . 8 5}$ & $\mathbf{1 8 9 . 5 3}$ & $\mathbf{1 9 2 . 3 8}$ \\
\hline
\end{tabular}

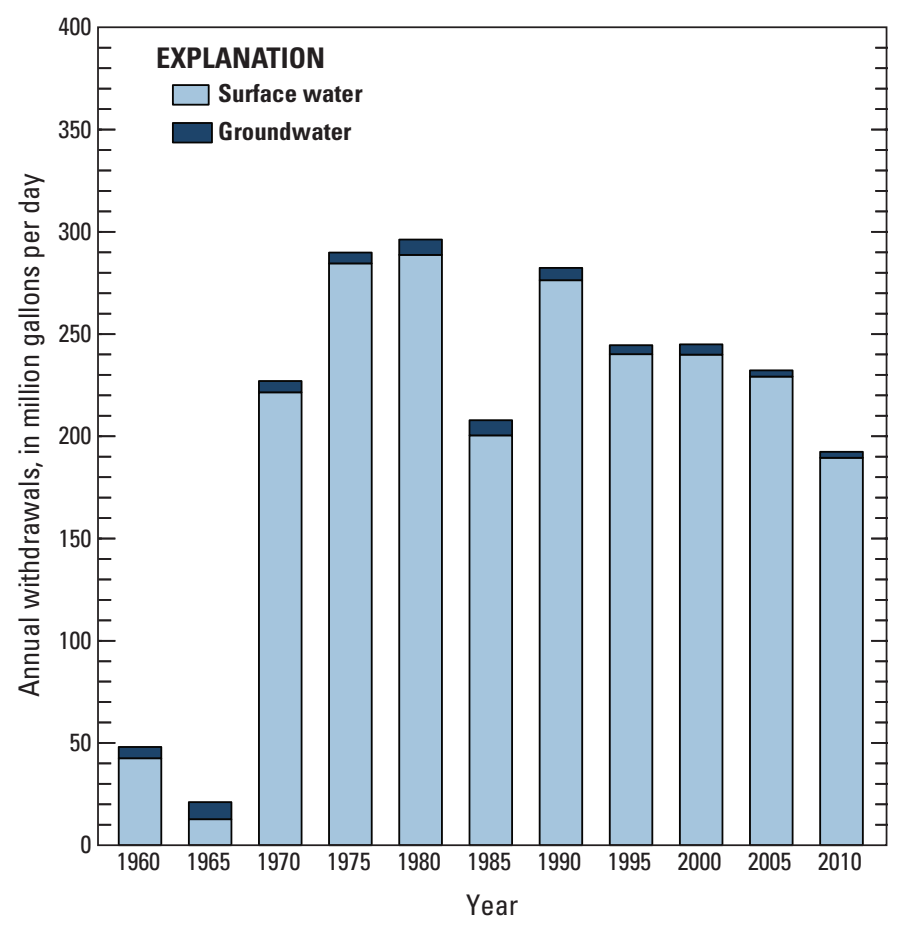

Figure 2. Water withdrawals in St. James Parish, Louisiana, 1960-2010 (Sargent, 2011).

\section{Groundwater Resources}

The primary aquifers that contain freshwater in areas of St. James Parish, from near surface to deepest, include the Mississippi River alluvial, Gramercy, and Norco aquifers (fig. 3). Deeper aquifers in St. James Parish generally contain only saltwater (water with chloride concentrations greater than 250 milligrams per liter $[\mathrm{mg} / \mathrm{L}])$; however, there are small areas of freshwater overlying saltwater in the deeper Gonzales-New Orleans aquifer in the northeastern and north-central parts of the parish (Tomaszewski, 2003). Mississippi River point-bar deposits and other local unnamed shallow sands are also present above the Gramercy aquifer and can provide limited quantities of freshwater; however, these aquifers are generally of limited extent and contain water that is very hard ${ }^{2}$ and has high iron concentrations (greater than 300 micrograms per liter $[\mu \mathrm{g} / \mathrm{L}]$ ) (Dial and Kilburn, 1980).

In St. James Parish, all of the aquifers that contain freshwater, except for the Gonzales-New Orleans aquifer, form a single interconnected hydrologic system. In many cases, Mississippi River point-bar deposits, the Mississippi River alluvial aquifer, and localized unnamed shallow sands provide a direct hydraulic connection to the Mississippi River for the Gramercy and Norco aquifers (Dial and Kilburn, 1980). A sizable connection has been observed where the Mississippi River alluvial, Gramercy, and Norco aquifers merge (fig. 3) to the west of Convent (Dial and Kilburn, 1980). The Gramercy and Norco aquifers are similar lithologically and are distinguished mainly on the basis of stratigraphic position. The Gonzales-New Orleans aquifer is more easily distinguished because of its uniform texture and because it is separated from the overlying Norco aquifer by a substantial layer of clay, reaching 150 feet (ft) thick in the central part of the parish (Dial and Kilburn, 1980).

The connections of the aquifers described above provide for both recharge and discharge by way of interaquifer flow and the Mississippi River. These connections also result in groundwater levels in the aquifers that fluctuate in response to river stage. In general, groundwater flows towards and discharges into the river; however, when river stage is high enough or when pumping has induced drawdown, Mississippi River water recharges the aquifers. The main source of freshwater recharge to the aquifers, however, is by infiltration of precipitation. Well withdrawals are also a source of discharge for the aquifers (Dial and Kilburn, 1980).

In 2010, groundwater withdrawals totaled about $2.83 \mathrm{Mgal} / \mathrm{d}$ for industrial use, $0.01 \mathrm{Mgal} / \mathrm{d}$ for rural-domestic use, and less than $0.01 \mathrm{Mgal} / \mathrm{d}$ for livestock (table 2). Groundwater withdrawals in St. James Parish were primarily from the Gramercy aquifer (2.84 Mgal/d), with $0.01 \mathrm{Mgal} / \mathrm{d}$ withdrawn from the Mississippi River alluvial aquifer and less than $0.01 \mathrm{Mgal} / \mathrm{d}$ withdrawn from the Norco aquifer (table 1).

\section{Mississippi River Alluvial Aquifer}

The Mississippi River alluvial aquifer is present and contains freshwater in roughly the southwestern half of St. James Parish (fig. 1; Tomaszewski, 2003). Generally, the upper part of the aquifer consists of fine to medium sand, and the lower part consists

${ }^{2}$ Hardness ranges, expressed as milligrams per liter of calcium carbonate, are as follows: 0-60, soft; 61-120, moderately hard; $121-180$, hard; greater than 180 , very hard (Hem, 1985). 


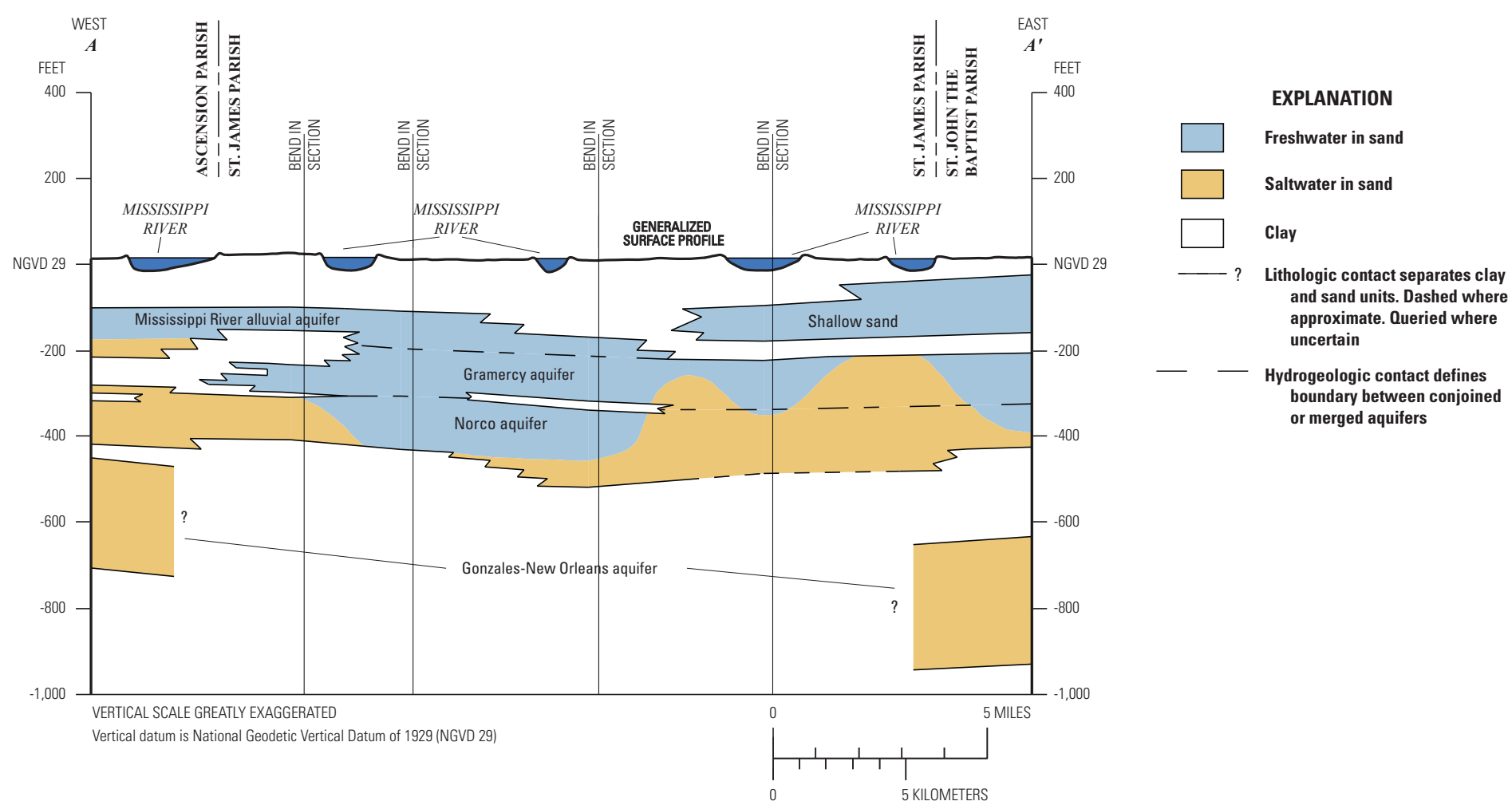

Figure 3. West-to-east hydrogeologic section through St. James Parish, Louisiana (modified from Griffith, 2003). Trace of section shown on figure 1.

of coarse sand and gravel. The base of the aquifer reaches a maximum depth of about $275 \mathrm{ft}$ below land surface in $\mathrm{St}$. James Parish. The alluvial aquifer is capable of yielding several thousand gallons per minute of freshwater that is generally hard, with high (greater than $300 \mu \mathrm{g} / \mathrm{L}$ ) iron concentrations (Tomaszewski, 2003).

State well-registration records listed 16 active water wells screened in the Mississippi River alluvial aquifer in St. James Parish in 2014, including 2 domestic, 3 industrial, 8 irrigation, and 3 public supply. Depths of these wells ranged from about 100 to $212 \mathrm{ft}$ below land surface. Reported yields from these wells ranged from 10 to 2,300 gallons per minute (gal/min) (Louisiana Department of Natural Resources, 2014).

\section{Gramercy Aquifer}

The Gramercy aquifer contains freshwater in St. James Parish in an irregular area extending from near the northwestern corner of the parish to the south-central part of the parish and in a much smaller area near the town of Gramercy (fig. 1). Grain size in the aquifer typically grades from fine sand at the top to coarse sand and fine gravel in the middle and lower parts of the aquifer (Dial and Kilburn, 1980). The aquifer is thin or missing in the north-central and northeastern parts of St. James Parish. Where the Gramercy aquifer is present in the parish, the top of the aquifer is about 175-200 ft below the National Geodetic Vertical Datum of 1929 (NGVD 29). Aquifer thickness ranges from less than $75 \mathrm{ft}$ to more than $225 \mathrm{ft}$, increasing generally from north to south (Dial and Kilburn, 1980). Water levels in the Gramercy aquifer reach seasonal highs in the spring and lows in the fall (fig. 4), coinciding with the seasonal high and low stages of the Mississippi River. The seasonal fluctuation in water levels in the aquifer decreases as the distance from the Mississippi River increases (Dial and Kilburn, 1980).

Freshwater quality from the Gramercy aquifer in St. James Parish varies depending on locality in response to inflow from adjacent sands and aquifers. This freshwater is generally hard to very hard and classified as a calcium-magnesium bicarbonate type (Hosman, 1972). The highest values of hardness are present in areas where the Gramercy aquifer is hydraulically connected with overlying Mississippi River point-bar deposits or shallow sands, except for a small area near Belmont where Gramercy aquifer water is soft. Freshwater in the Gramercy aquifer in St. James Parish generally exceeds the U.S. Environmental Protection Agency's Secondary Maximum Contaminant Levels ${ }^{3}$ (SMCLs) for color, iron, manganese, and dissolved solids (table 3; Dial and Kilburn, 1980).

State well-registration records listed 69 active water wells screened in the Gramercy aquifer in St. James Parish in 2014, including 25 domestic, 21 industrial, 19 irrigation, and 4 public supply. Well depths ranged from about 200 to $348 \mathrm{ft}$ below land surface. Reported yields from wells screened in the Gramercy aquifer in St. James Parish have ranged from 10 to 3,260 gal/min (Louisiana Department of Natural Resources, 2014).

\footnotetext{
${ }^{3}$ The SMCLs are nonenforceable Federal guidelines regarding cosmetic effects (such as tooth or skin discoloration) or aesthetic effects (such as taste, odor, or color) of drinking water. At high concentrations or values, health implications as well as aesthetic degradation may be present. SMCLs were established as guidelines for the States by the U.S. Environmental Protection Agency (1992).
} 


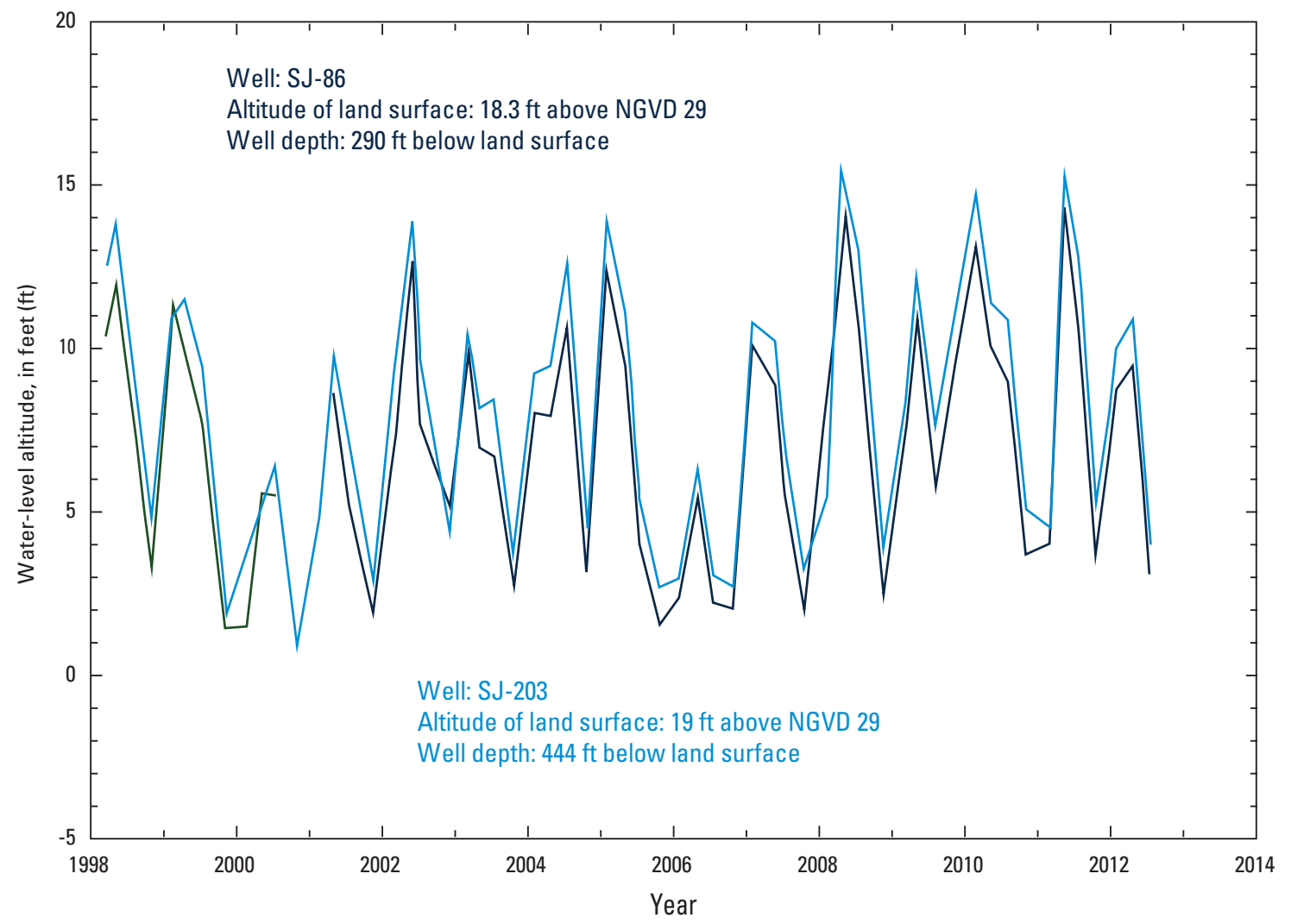

Figure 4. Water levels in well SJ-86 screened in the Gramercy aquifer and well SJ-203 screened in the Norco aquifer in St. James Parish, Louisiana (see fig. 1 for well locations; U.S. Geological Survey, 2012). Altitude of land surface and water level is measured in feet (ft) relative to the National Geodetic Vertical Datum of 1929 (NGVD 29).

\section{Norco Aquifer}

The Norco aquifer contains saltwater in most of St. James Parish. Freshwater in the aquifer is only available in a narrow lobe, extending from the northwestern parish border to as far south as St. James (fig. 1). The thickness of the Norco aquifer ranges from about 75 to $200 \mathrm{ft}$ within the parish, and the depth of the top of the aquifer ranges from about $250 \mathrm{ft}$ below NGVD 29 in the northeastern part of the parish to $450 \mathrm{ft}$ below NGVD 29 in the southern part of the parish. The aquifer is lithologically similar to the Gramercy aquifer; the upper part contains fine sand, and the lower part contains medium to coarse sand. Fine gravel may also be present in the lower part of the aquifer (Dial and Kilburn, 1980). Water levels in the Norco aquifer in St. James Parish (fig. 4) are also affected by the stage of the Mississippi River because of indirect hydraulic connection.

State well-registration records listed 16 active wells screened in the Norco aquifer in St. James Parish in 2014, including 7 domestic, 6 industrial, and 3 irrigation. Well depths ranged from about 340 to $528 \mathrm{ft}$ below land surface. Reported yields from these wells have ranged from 205 to $3,000 \mathrm{gal} / \mathrm{min}$ (Louisiana Department of Natural Resources, 2014).

Limited groundwater samples taken during the period 1938-89 from 12 freshwater wells screened in the Norco aquifer in St. James Parish indicated that hardness ranged from 40 to $420 \mathrm{mg} / \mathrm{L}$ as calcium carbonate, $\mathrm{pH}$ ranged from 6.5 to 8.5 , and chloride concentrations ranged from 7 to $230 \mathrm{mg} / \mathrm{L}$ (U.S. Geological Survey, 2014c).

\section{Surface-Water Resources}

In 2010, about $190 \mathrm{Mgal} / \mathrm{d}$ of surface water were withdrawn in the parish, including about $175 \mathrm{Mgal} / \mathrm{d}$ for industrial use, $11.8 \mathrm{Mgal} / \mathrm{d}$ for aquaculture, $3.12 \mathrm{Mgal} / \mathrm{d}$ for public supply, and $0.06 \mathrm{Mgal} / \mathrm{d}$ for general irrigation (table 2). All industrial and public supply water came from the Mississippi River. Most surface water withdrawn for industrial use was used for cooling purposes and was returned to its source after use (Sargent, 2011).

Surface-water drainages in St. James Parish are divided by the presence of higher natural elevations and constructed levees along the Mississippi River. This results in the Mississippi River being generally isolated from the surface-water flow in the rest of the parish. Rainfall generally flows away from the higher elevations along the river towards lower elevations through an intricate system of canals and streams. The area of the parish to the north of the Mississippi River is in the Lake Maurepas Basin (Hydrologic Unit Code [HUC] 08070204), which drains to the north and east through Bayou des Acadiens and Blind River (fig. 1) towards Lake Maurepas. The area of the parish to the south of the Mississippi River is in the East Central Louisiana Coastal Basin (HUC 08090301) and drains to the south and east through Bayous Verret, Citamon, and Chevreuil towards Lac des Allemands (fig. 1; U.S. Geological Survey, 1954, 2014a).

Very little streamflow or water-quality data are available for smaller streams in St. James Parish. Discharge statistics could not be computed; however, some water-quality constituent levels 
Table 3. Summary of selected water-quality characteristics of freshwater in the Gramercy aquifer in St. James Parish, Louisiana, 1931-2005 (U.S. Geological Survey, 2014c).

[Values are in milligrams per liter, except as noted. ${ }^{\circ} \mathrm{C}$, degrees Celsius; PCU, platinum cobalt units; $\mu \mathrm{S} / \mathrm{cm}$, microsiemens per centimeter; SU, standard units; $\mathrm{CaCO}_{3}$, calcium carbonate; $\mu \mathrm{g} / \mathrm{L}$, micrograms per liter; SMCL, Secondary Maximum Contaminant Level established by the U.S. Environmental Protection Agency (2012); NA, not applicable]

\begin{tabular}{|c|c|c|c|c|c|c|c|c|c|}
\hline & $\begin{array}{l}\text { Temper- } \\
\text { ature } \\
\left({ }^{\circ} \mathrm{C}\right)\end{array}$ & $\begin{array}{l}\text { Color } \\
\text { (PCU) }\end{array}$ & $\begin{array}{l}\text { Specific conduc- } \\
\text { tance, field } \\
\left(\mu \mathrm{S} / \mathrm{cm} \text { at } 25^{\circ} \mathrm{C}\right)\end{array}$ & $\begin{array}{l}\mathrm{pH}, \\
\text { field } \\
\text { (SU) }\end{array}$ & $\begin{array}{l}\text { Hardness } \\
\text { (as } \mathrm{CaCO}_{3} \text { ) }\end{array}$ & $\begin{array}{l}\text { Chloride, } \\
\text { filtered } \\
\text { (as CI) }\end{array}$ & $\begin{array}{c}\text { Iron, } \\
\text { filtered } \\
(\mu \mathrm{g} / \mathrm{L} \text { as Fe) }\end{array}$ & $\begin{array}{c}\text { Manganese, } \\
\text { filtered } \\
\text { ( } \mu \mathrm{g} / \mathrm{L} \text { as } \mathrm{Mn} \text { ) }\end{array}$ & $\begin{array}{l}\text { Dissolved } \\
\text { solids, } \\
\text { filtered }\end{array}$ \\
\hline \multicolumn{10}{|c|}{ Gramercy aquifer (70 wells) } \\
\hline Median & 21.0 & 20 & 802 & 7.4 & 220 & 46 & 600 & 130 & 550 \\
\hline 10th percentile & 20.0 & 4 & 479 & 6.9 & 26 & 13 & 100 & 19 & 311 \\
\hline 90th percentile & 21.5 & 55 & 1,180 & 7.9 & 390 & 150 & 3,900 & 450 & 803 \\
\hline Number of samples & 45 & 27 & 60 & 46 & 68 & 70 & 34 & 20 & 24 \\
\hline $\begin{array}{l}\text { Percentage of samples } \\
\text { that do not exceed } \\
\text { SMCLs }\end{array}$ & NA & 37 & NA & 98 & NA & 100 & 29 & 30 & 42 \\
\hline \multicolumn{10}{|c|}{ SMCLs } \\
\hline & NA & 15 & NA & $6.5-8.5$ & NA & 250 & 300 & 50 & 500 \\
\hline
\end{tabular}

have been measured. Five water samples taken from Blind River (site number 07380222; fig. 1) during 1967-2005 indicated a $\mathrm{pH}$ range of 6.8-7.2, a dissolved oxygen range of $3.6-7.5 \mathrm{mg} / \mathrm{L}$, a hardness range of $65-140 \mathrm{mg} / \mathrm{L}$ as calcium carbonate, a chloride range of $25-199 \mathrm{mg} / \mathrm{L}$, and a dissolved solids range of $122-518 \mathrm{mg} / \mathrm{L}$. Four water samples taken in 1999 from Bayou Chevreuil (site number 07380270; fig. 1) indicated a pH range of 6.7-7.3, a dissolved oxygen concentration of $3.5 \mathrm{mg} / \mathrm{L}$, a hardness range of $71-105 \mathrm{mg} / \mathrm{L}$ as calcium carbonate, a chloride range of $19-89 \mathrm{mg} / \mathrm{L}$, a manganese range of $148-177 \mathrm{mg} / \mathrm{L}$, and a dissolved solids range of 142-290 mg/L (U.S. Geological Survey, 2014c). A dissolved oxygen concentration of $5 \mathrm{mg} / \mathrm{L}$ is considered the minimum value for a diversified population of fresh, warmwater biota, including sport fish (Louisiana Department of Environmental Quality, 2008).

\section{Mississippi River}

The Mississippi River, which divides St. James Parish into northern and southern parts, is the primary source of fresh surface water in the parish. The Mississippi River drains more than 40 percent of the continental United States. Water quality and quantity in the Mississippi River are affected by both natural processes and human activities in the Mississippi River Basin upstream of St. James Parish. These processes and activities include precipitation, erosion, and the effects of dams and diversions. Water quantity and quality both vary seasonally because of the rate and distribution of precipitation and land-use patterns.

Water quantity can vary appreciably as indicated by record discharges at Baton Rouge, Louisiana, located about 54 river miles upstream of the St. James Parish border (site number 07374000; fig. 1 index map), of 1,436,000 cubic feet per second $\left(\mathrm{ft}^{3} / \mathrm{s}\right)$ in May 2011 and 132,800 ft $\mathrm{ft}^{3} / \mathrm{s}$ in October 2012 (U.S. Geological Survey, 2014d). The average flow of the Mississippi River near Red River Landing, Louisiana (site number 07373291; fig. 1 index map), located about 125 river miles upstream of Union, was about $460,000 \mathrm{ft}^{3} / \mathrm{s}$ (about 298,000 Mgal/d) during 1928-76 (Wells, 1980). The flow in the Mississippi River at Red River Landing is representative of flows in St. James Parish because there are no major tributaries or distributaries, and the river is mostly leveed between the landing and the parish.

Water quality is also affected by runoff, discharge, and contamination from upstream agricultural, municipal, and industrial activities. Water-quality constituent concentrations, such as agricultural pesticides and nutrients, are generally highest in June and July, representing the "spring flush," which results from the runoff of upstream applications of these pesticides and nutrients (Demcheck and others, 2004). Suspended-sediment concentrations are generally highest in late winter and early spring and lowest in late summer and fall (Wells, 1980). Water samples analyzed during the period 1973-93 indicated that water in the Mississippi River at Union (site number 07374220; fig. 1) is generally hard and usually does not exceed the SMCLs for $\mathrm{pH}$ and concentrations of chloride, sulfate, and iron (table 4). Dissolved oxygen concentrations are generally greater than $5 \mathrm{mg} / \mathrm{L}$.

\section{References Cited}

Demcheck, D.K.; Tollett, R.W.; Mize, S.V.; Skrobialowski, S.C.; Fendick, R.B., Jr.; Swarzenski, C.M.; and Porter, Stephen, 2004, Water quality in the Acadian-Pontchartrain Drainages, Louisiana and Mississippi, 1999 2001: U.S. Geological Survey Circular 1232, 41 p.

Dial, D.C., and Kilburn, Chabot, 1980, Ground-water resources of the Gramercy area, Louisiana: Louisiana Department of Transportation and Development, Office of Public Works Water Resources Technical Report no. 24, 39 p. 
Table 4. Summary of selected water-quality characteristics for the Mississippi River at Union, Louisiana (U.S. Geological Survey, 2014c).

[Values are in milligrams per liter, except as noted. $\mu \mathrm{S} / \mathrm{cm}$, microsiemens per centimeter; ${ }^{\circ} \mathrm{C}$, degrees Celsius; $\mathrm{SU}$, standard units; $\mathrm{CaCO}_{3}$, calcium carbonate; $\mu \mathrm{g} / \mathrm{L}$, micrograms per liter; <, less than; SMCL, Secondary Maximum Contaminant Level established by the U.S. Environmental Protection Agency (2012); NA, not applicable]

\begin{tabular}{|c|c|c|c|c|c|c|c|c|}
\hline $\begin{array}{c}\text { Specific } \\
\text { conduc- } \\
\text { tance, field } \\
(\mu \mathrm{S} / \mathrm{cm} \\
\left.\text { at } 25^{\circ} \mathrm{C}\right)\end{array}$ & $\begin{array}{l}\text { Oxygen, } \\
\text { dissolved }\end{array}$ & $\begin{array}{l}\mathrm{pH}, \\
\text { field } \\
\text { (SU) }\end{array}$ & $\begin{array}{l}\text { Hardness } \\
\text { (as } \mathrm{CaCO}_{3} \text { ) }\end{array}$ & $\begin{array}{l}\text { Calcium, } \\
\text { filtered } \\
\text { (as Ca) }\end{array}$ & $\begin{array}{l}\text { Magne- } \\
\text { sium, } \\
\text { filtered } \\
\text { (as Mg) }\end{array}$ & $\begin{array}{l}\text { Sodium, } \\
\text { filtered } \\
\text { (as } \mathrm{Na} \text { ) }\end{array}$ & $\begin{array}{c}\text { Chloride, } \\
\text { filtered } \\
\text { (as CI) }\end{array}$ & $\begin{array}{l}\text { Sulfate, } \\
\text { filtered } \\
\text { (as } \mathrm{SO}_{4} \text { ) }\end{array}$ \\
\hline
\end{tabular}

\begin{tabular}{|c|c|c|c|c|c|c|c|c|c|c|}
\hline \multicolumn{11}{|c|}{ Mississippi River at Union, 1973-931 } \\
\hline Median & 386 & 8.2 & 7.6 & 150 & 39 & 12 & 16 & 21 & 46 & 20 \\
\hline 10th percentile & 300 & 6.3 & 7.2 & 120 & 31 & 8.9 & 12 & 15 & 34 & $<10$ \\
\hline 90th percentile & 485 & 11.4 & 7.9 & 170 & 45 & 16 & 27 & 33 & 67 & 60 \\
\hline Number of samples & 305 & 299 & 296 & 299 & 274 & 275 & 53 & 303 & 299 & 296 \\
\hline $\begin{array}{l}\text { Percentage of samples } \\
\text { that do not exceed } \\
\text { SMCLs }\end{array}$ & NA & NA & 100 & NA & NA & NA & NA & 100 & 100 & 99 \\
\hline \multicolumn{11}{|c|}{ SMCLS } \\
\hline & NA & NA & $6.5-8.5$ & NA & NA & NA & NA & 250 & 250 & 300 \\
\hline
\end{tabular}

${ }^{1}$ Site number 07374220 .

Griffith, J.M., 2003, Hydrogeologic framework of southeastern Louisiana: Louisiana Department of Transportation and Development Water Resources Technical Report no. 72, 21 p., 18 pls.

Hem, J.D., 1985, Study and interpretation of the chemical characteristics of natural water (3d ed.): U.S. Geological Survey Water-Supply Paper 2254, 264 p., accessed February 20, 2013, at http://pubs.er.usgs.gov/publication/ wsp2254.

Hosman, R.L., 1972, Ground-water resources of the Norco area, Louisiana: Department of Conservation, Louisiana Geological Survey, and Louisiana Department of Public Works Water Resources Bulletin no. 18, 61 p.

Louisiana Department of Environmental Quality, 2008, Environmental Regulatory Code, Title 33, Part IX, Subpart 1: Baton Rouge, Louisiana Department of Environmental Quality, accessed June 9, 2009, at http:www. deq.louisiana.gov/portal/tabid/1674/Default.aspx.

Louisiana Department of Natural Resources, 2014, Strategic Online Natural Resources Information System (SONRIS): Louisiana Department of Natural Resources database, accessed October 28, 2014, at http://sonris.com/.

Sargent, B.P., 2011, Water use in Louisiana, 2010: Louisiana Department of Transportation and Development Water Resources Special Report no. 17, $135 \mathrm{p}$.

Tomaszewski, D.J., 2003, Groundwater resources along the lower Mississippi River, southeastern Louisiana: Louisiana Department of Transportation and Development Water Resources Technical Report no. 69, 23 p.

U.S. Environmental Protection Agency, 1992, Secondary Drinking Water Regulations - Guidance for nuisance chemicals: U.S. Environmental Protection Agency publication EPA 810/K-92-001, 4 p., accessed September 28, 2011, at http://water.epa.gov/drink/contaminants/secondarystandards.cfm.

U.S. Environmental Protection Agency, 2012, 2012 Edition of the drinking water standards and health advisories: U.S. Environmental Protection Agency publication EPA 822-S-12-001, Office of Water, 12 p., accessed August 7, 2012, at http://water.epa.gov/action/advisories/drinking/upload/ dwstandards2012.pdf.

U.S. Geological Survey, [Turcan, A.N., Jr.], [1954], Water, in St. James Parish Resources and Facilities: St. James Parish Planning and Development Board and Louisiana Department of Public Works, p. 27-33.

U.S. Geological Survey, 2012, Ground-water levels for Louisiana [data for USGS 300024090433501 SJ-86]: National Water Information System Web Interface, accessed October 18, 2012, at http://nwis.waterdata.usgs.gov/la/ nwis/gwlevel/.

U.S. Geological Survey, 2014a, Science in your watershed: Accessed October 28, 2014, at http://water.usgs.gov/wsc/reg/08.html.
U.S. Geological Survey, 2014b, U.S. Geological Survey Water Resources Cooperative Program: Louisiana Water Use Program, 1960-2010 data, accessed September 3, 2014, at http://la.water.usgs.gov/WaterUse/default. asp.

U.S. Geological Survey, 2014c, Water quality samples for Louisiana: National Water Information System Web Interface, accessed August 6, 2014, at http:// nwis.waterdata.usgs.gov/la/nwis/qwdata/.

U.S. Geological Survey, 2014d, Water-resources data for the United States, water year 2013: U.S. Geological Survey Water-Data Report WDR-US-2013, site 07374000, accessed August 19, 2014, at http://wdr.water.usgs.gov/ wy2013/pdfs/07374000.2013.pdf.

Wells, F.C., 1980, Hydrology and water quality of the lower Mississippi River: Louisiana Department of Transportation and Development, Office of Public Works Water Resources Technical Report no. 21, 83 p.

This fact sheet was published by the U.S. Geological Survey in cooperation with the Louisiana Department of Transportation and Development (DOTD). Thanks are given to Zahir "Bo" Bolourchi, Director, Water Resources Programs, Louisiana DOTD, who contributed to the content of the fact sheet.

\section{By Vincent E. White and Lawrence B. Prakken}

\section{For additional information, contact:}

Director, USGS Lower Mississippi-Gulf Water Science Center 3535 S. Sherwood Forest Blvd., Suite 120

Baton Rouge, LA 70816

E-mail: gs-w-lmg_center_director@usgs.gov

Fax: (225) 298-5490

Telephone: (225) 298-5481

Home Page: http://la.water.usgs.gov 